\title{
The Influence of Work Environment and Perceived Organizational Support on the Employee Performance of PT Y in Surabaya with Employee Engagement as an Intervening Variable
}

\author{
Audina Anggraini, Hermien Tridayanti, Elok Damayanti \\ Faculty of Economy and Business, Management Study Program \\ Narotama University Surabaya, Indonesia \\ anggrainiaudina7@gmail.com, hermien.tridayanti@narotama.ac.id, \\ elok.damayanti@narotama.ac.id
}

\begin{abstract}
This study aims to determine the influence of work environment and perceived organizational support on the employee's performance of PT Y in Surabaya, both directly or indirectly with employee engagement as an intervening variable. This research is a quantitative study. Population and sample based on the distribution of questionnaires to the performance of the employees of PT Y in Surabaya was taken as many as 30 respondents. Data collection techniques used interviews, observations, and questionnaires. For statistical tests and the processing of data is carried out by using the partial least square (Smart PLS 3.0). The study showed that each variable, work environment and perceived organizational support had a direct significant influence on employee performance and employee engagement. Work environment had a direct significant effect on employee performance with a t-statistical value of 2.136 greater than the indirect effect through employee engagement as an intervening variable with a t-statistics value of 1.454 . While perceived organizational support had a direct effect on employee performance with t-statistics of 2.550 is greater when compared to the indirect effect through employee engagement as an intervening variable with t-statistics 2.042 .
\end{abstract}

\section{Keywords :}

Employee Engagement, Employee Performance, Perceived Organizational Support, Work Environment

\section{Introduction}

In the current era of globalization, the business world has had a very real impact. The real impact can be seen with the intense competition that arises between companies to get the targeted market share. In order for companies to be able to compete and survive, companies must have a strategy to get the attention of consumers. One strategy that can be done is to improve the quality of the products.

One of the important aspects in a company to improve product quality is human resources. The existence of optimal human resources equipped with good performance that the company wants is the right combination in running the company. According to (Onita Sari Sinaga \& Abdurrozaq Hasibuan, 2020), performance is a result that is done in order to achieve organizational goals which are carried out legally, do not violate the law and are in accordance with the morals and responsibilities given to them. (Onita Sari Sinaga \& Abdurrozaq Hasibuan, 2020)

Likewise with PT Y in Surabaya as a manufacturing company engaged in converting \& flexible packaging which has been established since 1986. PT Y in Surabaya has produced products for the domestic and international markets. This company has printed various kinds of packaging for almost all types of products such as food, beverages, snacks, detergents, cigarette packaging, and so on. PT Y in Surabaya has a vision of "Customer satisfaction is a target and pride, for the good of both customers and us". The number of new companies engaged in the same field, especially in the city of Surabaya, makes it a tough competition for PT Y in Surabaya to improve product quality and customer satisfaction.

In addition to implementing the company's strategy in facing competition, high employee performance is expected by the company to achieve the company's vision and profits. Employees are required to be able to carry out their jobs optimally so as to produce quality products and according to the standards desired by customers.

The performance problems that are happening at PT Y in Surabaya are related to the not yet optimal performance of employees to produce products that pass consumer standards and do not returns. This indication 
can be seen from the unachieved maximum target of company returns, which is $0.50 \%$. The following researchers present a recap of returns during the first semester of 2020 :

Table 1. Recap of Returns During $1^{\text {st }}$ Semester of 2020

\begin{tabular}{ccccccc}
\hline \multirow{2}{*}{ Month } & \multicolumn{2}{c}{ Roll's Quantity } & Total Return's & Return's & \multicolumn{2}{c}{$\begin{array}{c}\text { Precentage of Returns } \\
\text { Handling }\end{array}$} \\
& Sold & Returns & & & Destroyed & Reprocessed \\
\hline January & 94.860 & 919 & $9.254,1 \mathrm{~kg}$ & $0,72 \%$ & $0,53 \%$ & $0,19 \%$ \\
February & 83.863 & 941 & $12.773,1 \mathrm{~kg}$ & $0,89 \%$ & $0,54 \%$ & $0,34 \%$ \\
March & 90.552 & 1.139 & $18.152,1 \mathrm{~kg}$ & $0,94 \%$ & $0,56 \%$ & $0,37 \%$ \\
April & 106.828 & 1.201 & $21.011,2 \mathrm{~kg}$ & $0,79 \%$ & $0,41 \%$ & $0,38 \%$ \\
May & 76.124 & 983 & $17.681,3 \mathrm{~kg}$ & $0,92 \%$ & $0,62 \%$ & $0,30 \%$ \\
June & 105.228 & 1568 & $23.166,8 \mathrm{~kg}$ & $1,19 \%$ & $0,73 \%$ & $0,46 \%$ \\
\hline
\end{tabular}

Source: Internal Data of PT Y in Surabaya

Regarding the results of the returns recap above, it can be concluded that during the first semester of 2020 the percentage of PT Y's returns was still above the company's maximum limit. The department that is directly responsible for product quality is the quality control department. So, researchers conducted interviews with a number of employees of the quality control department and the head of the quality control department regarding performance in checking product quality. The results show that the work environment and perceived organizational support are the factors most frequently complained of by employees, which are indicated to be the causes of less than optimal performance in checking quality products. Following are the results of a survey conducted in the quality control department regarding the working environment conditions at PT Y in Surabaya:

Table 2. Survey Results Related to Work Environment Conditions

\begin{tabular}{cccccc}
\hline \multirow{2}{*}{ No } & \multirow{2}{*}{ Indicator } & Number of employees & \multicolumn{2}{c}{ Precentage } \\
& & Satisfied & Unsatisfied & Satisfied & Unsatisfied \\
\hline 1 & Workplace lighting & 15 & 15 & $50,00 \%$ & $50,00 \%$ \\
2 & Temperature at workplace & 11 & 19 & $36,67 \%$ & $63.33 \%$ \\
3 & Noise at workplace & 12 & 18 & $40,00 \%$ & $60,00 \%$ \\
4 & Mechanical vibrations at workplace & 13 & 17 & $43,33 \%$ & $56,67 \%$ \\
5 & Bad smell at workplace & 14 & 16 & $46,67 \%$ & $53,33 \%$ \\
6 & Workplace atmosphere & 12 & 18 & $40,00 \%$ & $60,00 \%$ \\
7 & Relationships with coworkers & 20 & 10 & $66,67 \%$ & $33,33 \%$ \\
8 & Availability of work facilities & 12 & 18 & $40,00 \%$ & $60,00 \%$ \\
9 & Safety at workplace & 14 & 16 & $46,67 \%$ & $53,33 \%$ \\
& Mean & & $45,56 \%$ & $54,44 \%$ \\
\hline
\end{tabular}

The survey results show that the percentage of employees who are dissatisfied with the work environment is higher than the percentage of employees who are satisfied with the current work environment. This can be the cause of less than optimal employee performance in checking product quality before it reaches consumers. (Nitisemito, 2014), explains that the work environment is everything that is around the workers and which can affect the workers themselves in carrying out the tasks assigned to them. (Fauzi \& Nugroho, 2020)

Another factor that affects the performance of employees at PT Y is perceived organizational support. Companies and employees have a reciprocal relationship. When employees feel supported by the company, they feel obliged to repay this support through optimal performance. This belief that arises is what is meant by perceived organizational support. (Eisenberger et al., 2001) explain that perceived organizational support is the employee's perception of the company regarding the extent to which the company provides support to employees (Eisenberger et al., 2001).

The results of interviews with the head of the quality control department related to the implementation of the job description showed that there were still many employees who did not exert their optimal performance skills and were highly dedicated to their work. This is indicated by the problems that are still frequently found by department heads in customer complaints and returns reports. The following researchers present in table form: 


\section{JURNAL EKONOMI}

Table 3. Recap of Complaints and Customer Returns for $1^{\text {st }}$ Of 2020

\begin{tabular}{ccccccc}
\hline \multirow{2}{*}{ Month } & \multicolumn{3}{c}{ Percentage of Problem Returns } & Returns & Returns \\
& Printing & Laminating & Dry & Slitting & & Destroyed \\
& Finish Good \\
\hline January & $64,08 \%$ & $1,59 \%$ & $10,55 \%$ & $23,78 \%$ & $73,50 \%$ & $26,50 \%$ \\
February & $54,58 \%$ & $3,07 \%$ & $1,86 \%$ & $40,43 \%$ & $61,30 \%$ & $38,70 \%$ \\
March & $33,86 \%$ & $6,24 \%$ & $14,42 \%$ & $45,48 \%$ & $60,10 \%$ & $39,90 \%$ \\
April & $29,47 \%$ & $3,10 \%$ & $11,20 \%$ & $56,23 \%$ & $52,50 \%$ & $47,50 \%$ \\
May & $47,64 \%$ & $0,05 \%$ & $3,01 \%$ & $49,30 \%$ & $67,00 \%$ & $33,00 \%$ \\
June & $78,55 \%$ & $0,39 \%$ & $4,19 \%$ & $16,87 \%$ & $61,40 \%$ & $38,60 \%$ \\
\hline
\end{tabular}

Source: Internal Data of PT Y in Surabaya

From the table above, it shows that the sense of engagement and commitment of employees at PT Y to exert all their abilities and work above average to produce the good quality products is still lacking. This is interpreted by the high level of customer complaints regarding the quality of the products produced. Commitment to job success is known as employee engagement. It has been defined by one of the leading research organizations that employee engagement is a high emotional connection that an employee feels towards his company which influences him to exert more and more free effort for his work.

From some of the data that has been collected and the results of interviews with the quality control department, it can be concluded that it is necessary to make efforts to improve the work environment at PT Y in Surabaya and perceived organizational support for employees of the quality control department. By increasing perceived organizational support and the work environment, it is hoped that it will strengthen employee engagement. So that employee performance will increase and can produce quality products and according to standards according to customers.

Based on this phenomenon, the author tries to conduct research presented in the thesis entitled:

Many factors affect employee performance, including work environment, perceived organizational support, employee engagement, and other factors beyond this research. The object of this research is PT $\mathrm{Y}$ in Surabaya. Referring to the description above, the problem formulation submitted are :

1. Does work environment have a significant effect on the employee engagement of PT Y in Surabaya?

2. Does perceived organizational support have a significant effect on the employee engagement of PT Y in Surabaya?

3. Does work environment have a significant effect on the performance of PT Y employees?

4. Does perceived organizational support have a significant effect on the performance of PT Y employees?

5. Does employee engagement have a significant effect on the performance of PT Y employees?

6. Does employee engagement mediate the effect of the work environment on the performance of PT Y employees?

7. Does employee engagement mediate the effect of the perceived organizational support on the performance of PT Y employees?

\section{Literature Review}

\subsection{Work Environment}

According to (Sedarmayanti \& Rahadian, 2018), work environment is a place for a number of groups in which there are several supporting facilities to achieve company goals in accordance with the company's vision and mission. Meanwhile, Nitisemito defines the work environment as a source of information and a place to carry out activities, so that a good working environment must be created so that employees feel more at home and comfortable in the workspace to complete their work, so that a high level of efficiency can be achieved (Sudaryo et al., 2018). The type of work environment is divided into 2, namely: 1) physical work environment, which is all physical conditions that exist around the workplace that can affect employees either directly or indirectly. 2) non-physical work environment is all situations that occur in connection with work relationships, both relationships with superiors, relationships with coworkers, or relationships with subordinates (Rahman, 2017).

\subsection{Perceived Organizational Support}

. (Eisenberger et al., 2001) define Perceived organizational support as employees 'beliefs about the extent to which the company / organization appreciates employees' contributions and cares about their welfare. When the organization provides sufficient support to employees, the organization gets a level of acceptance and desire for the resulting performance (Baliartati, 2016). Based on the theory of perceived organizational support by 
(Eisenberger et al., 2002), there are three general forms of action from organizations that are perceived to increase perceived organizational support, namely the principle of fairness, rewards from organizations and job conditions (organizational rewards and job conditions) and support from superiors (supervisory support) (Eisenberger et al., 2001). (Eisenberger et al., 2002) reveal that perceived organizational support has been found to be associated with beneficial results or rewards, for example job satisfaction, organizational commitment, and employee performance (Onita Sari Sinaga \& Abdurrozaq Hasibuan, 2020).

\subsection{Employee Engagement}

According to Schaufeli and Bakker, employee engagement is positive thinking, to accomplish things related to work and is characterized by vigor (energy and mental resilience at work), dedication (participating in work experiences a sense of enthusiasm and challenges), and absorption (concentration and pleasure in working) (Arnold b bakker \& michael p leiter, 2010). The conference board stated that employee engagement is a strong relationship both emotionally and intellectually that employees feel towards the organization, job, managers, colleagues, which will influence employees to put more effort into their work.

\subsection{Work Performance}

According to Sutrisno et al., (2016) performance is the result that someone has achieved from their work behavior in carrying out work activities. Meanwhile, according to Bani, (2013) the definition of performance is the quality and quantity of work achieved by an employee in carrying out his duties in accordance with the responsibilities assigned to him. Performance is organizational behavior that is directly related to work activities, task achievement where the term task comes from the thought of activities required by work (Hasibuan, 2010). According to Harsuko, (2011), performance is the extent to which a person has played for him / her in implementing organizational strategy, both in achieving specific goals related to individual roles and or by showing competencies that are declared relevant to the organization. Performance is a multidimensional concept that includes three aspects, namely attitude, ability and accomplishment (Fauzi \& Nugroho, 2020).

\subsection{Framework}

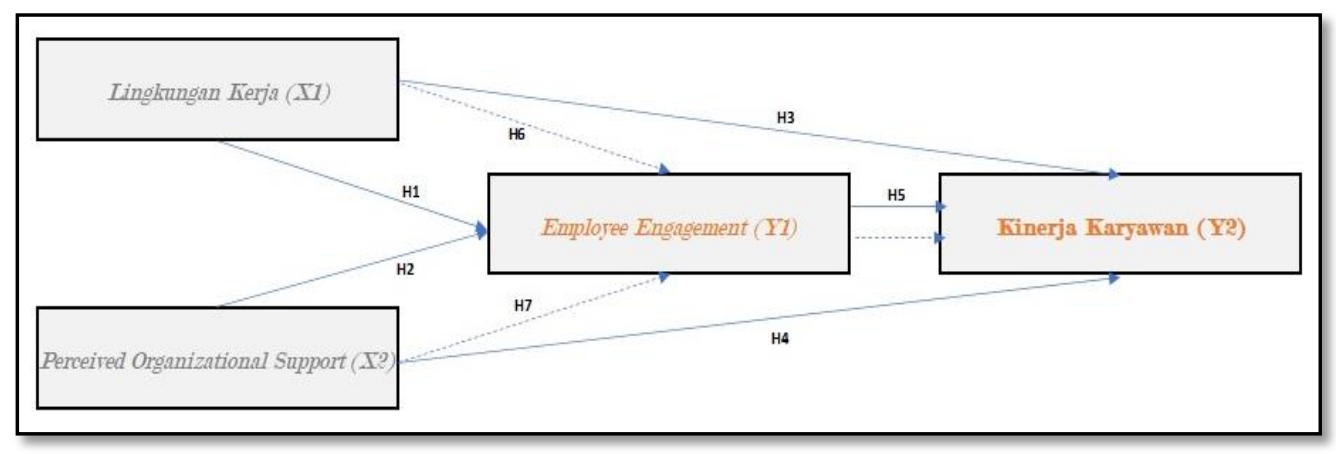

Figure 1. Research Conceptual Framework

\subsection{Research Hypothesis}

Based on the explanation above, the following research hypothesis can be proposed :

1. H1: Work environment has a positive and significant effect on employee engagement of PT Y in Surabaya

2. H2: Perceived organizational support has a positive and significant effect on employee engagement of PT Y in Surabaya

3. H3: Work environment has a positive and significant effect on the performance of PT Y employees

4. H4: perceived organizational support has a positive and significant effect on the performance of PT Y employees

5. H5: Employee engagement has a positive and significant effect on the performance of PT Y employees

6. H6: Work environment has a positive and significant effect on the performance of PT Y Employees with employee engagement as an intervening variable

7. H7: Perceived organizational support has a positive and significant effect on the performance of PT Y Employees with employee engagement as an intervening variable. 


\section{JURNAL EKONOMI}

\section{Methodology}

\subsection{Population and Sample}

According to Sugiyono, (2016) population is a generalization area consisting of objects or subjects that have certain qualities and characteristics determined by researchers to be studied and then drawn conclusions. The population in this study are employees of PT Y in Surabaya, amounting to 30 resource based on the amount of employees in the department.

\subsection{Data Analysis Method}

The analytical method used is the quantitative method by operationalizing the work environment variable $\left(\mathrm{X}_{1}\right)$, perceived organizational support $\left(\mathrm{X}_{2}\right)$ employee engagement $\left(\mathrm{Y}_{1}\right)$. employee performance $\left(\mathrm{Y}_{2}\right)$.

In this study, researchers used the partial least square method using smart PLS version 3.0 software.

There are three stages of analysis in Partial Least Square:

1. Outer Model Analysis (Measurement Model)

2. Inner Model Analysis (Structural Model)

3. Hypothesis Testing.

\section{Result and Discussion}

\subsection{Description of Research Results}

Respondents in this study were employees of PT Y in Surabaya, amounting to 30 people. The collection of primary data is done by giving questionnaires to the employees of PT Y in Surabaya by spreading. Characteristics of respondents based on gender, age, and years of work. Respondent characteristics are presented in the following table :

Table 4. Samples and Returns Questionnaire

\begin{tabular}{ccc}
\hline Description & Amount & Percentage \\
\hline Total distribution of questionnaires & 30 & $100 \%$ \\
Total returns of questionnaires & 30 & $100 \%$ \\
Processed questionnaires & 30 & $100 \%$ \\
\hline Source : Primary Data Processed (2021)
\end{tabular}

Based on table 4. above shows that 30 questionnaires were distributed, 30 returned questionnaires, and 30 questionnaires that could be processed and analyzed.

\subsection{Characteristics of Respondents by Gender}

Based on the results of the questionnaire distribution of 30 respondents obtained the characteristics of respondents by sex can be seen in the table below :

Table 5. Characteristics of Respondents by Gender

\begin{tabular}{ccccc}
\hline & Frequency & Percent & Valid Percent & $\begin{array}{c}\text { Cumulative } \\
\text { Percent }\end{array}$ \\
\hline Male & 25 & 83.0 & 83.0 & 83.0 \\
Female & 5 & 17.0 & 17.0 & 100.0 \\
Total & 30 & 100.0 & 100.0 & \\
\hline
\end{tabular}

Source : Primary Data Processed (2021)

Based on table 5. it can be seen that the highest number of respondents by sex is male with a percentage of $83 \%$ or ( 25 people) while the percentage of female respondents is $17 \%$ or (5 people).

\subsection{Characteristics of Respondents by Age}

Based on the results of the distribution of 30 respondents questionnaire obtained respondent characteristics based on age can be seen in the table below : 
Table 6. Characteristics of Respondents by Age

\begin{tabular}{ccccc}
\hline & Frequency & Percent & Valid Percent & $\begin{array}{c}\text { Cumulative } \\
\text { Percent }\end{array}$ \\
\hline $21-29$ years old & 8 & 27.0 & 27.0 & 27.0 \\
$30-39$ years old & 5 & 17.0 & 17.0 & 43.0 \\
$40-49$ years old & 13 & 43.0 & 43.0 & 87.0 \\
Above 50 years old & 4 & 13.0 & 13.0 & 100.0 \\
Total & 30 & 100.0 & 100.0 & \\
\hline
\end{tabular}

Source : Primary Data Processed (2021)

Based on table 6 it can be seen that the largest number of respondents is respondents aged 40 - 49 years, namely as many as 13 people or by $43 \%$. Meanwhile, the respondents who were at least over 50 years old were 4 people or $13 \%$. For respondents aged 21-29 years as many as 8 people or $27 \%$. And for respondents aged 3039 years as many as 5 people or $17 \%$. This shows that the majority of employees of the quality control department at PT Y Surabaya are 40 - 49 years old.

\subsection{Characteristics of Respondents by Years of Work}

Based on the results of the distribution of 30 respondents questionnaire obtained respondent characteristics based on years of work can be seen in the table below :

Table 7. Characteristics of Respondents by Years of Work

\begin{tabular}{ccccc}
\hline & Frequency & Percent & $\begin{array}{c}\text { Valid } \\
\text { Percent }\end{array}$ & $\begin{array}{c}\text { Cumulative } \\
\text { Percent }\end{array}$ \\
\hline 0 - 5 years & 6 & 20.0 & 20.0 & 20.0 \\
$6-10$ years & 7 & 23.0 & 23.0 & 43.0 \\
above 10 years & 17 & 57.0 & 57.0 & 100.0 \\
Total & 30 & 100.0 & 100.0 & \\
\hline & Source : Primary Data Processed (2021)
\end{tabular}

Based on table 7. regarding the characteristics of respondents according to years of work, it can be seen that the largest number of respondents were respondents with a service period of more than 10 years, namely 17 people or $57 \%$. Furthermore, respondents with a work period of 6-10 years were 7 people or $23 \%$. And the least is the respondents with a working period of 0 - 5 years, namely as many as 6 people or $20 \%$. This shows that the majority of quality control department employees have a service period of more than 10 years.

\subsection{Variable Description}

To facilitate the assessment of the results of the distribution of questionnaires in this study by categorizing the average responses of respondents to each of the indicators of questions that have been raised. Values 1 and 5 come from the highest and lowest scores on the questionnaire. A summary of the results of the category provisions that apply to the variables observed in this study are as follows:

Table 8. Rating Category

\begin{tabular}{ccc}
\hline Interval & Category & Value \\
\hline $4,20<\mathrm{a} \leq 5,00$ & Strongly agree & 5 \\
$3,40<\mathrm{a} \leq 4,20$ & Agree & 4 \\
$2,60<\mathrm{a} \leq 3,40$ & Ordinary & 3 \\
$1,80<\mathrm{a} \leq 2,60$ & Disagree & 2 \\
$1,00<\mathrm{a} \leq 1,80$ & Strongly disagree & 1 \\
\hline \multicolumn{2}{c}{ Source $:$ Primary Data Processed (2021) }
\end{tabular}




\section{JURNAL EKONOMI}

Based on the questionnaire given to 30 respondents, the following is the percentage distribution for each research instrument :

Description of Work Environment Variables $\left(\mathrm{X}_{1}\right)$

Table 9. Respondents Response Regarding Work Environment $\left(\mathrm{X}_{1}\right)$

\begin{tabular}{|c|c|c|c|c|c|c|c|c|c|c|c|c|c|}
\hline \multirow{2}{*}{$\begin{array}{c}\text { Ite } \\
\text { m }\end{array}$} & \multicolumn{2}{|c|}{ STS } & \multicolumn{2}{|c|}{$\mathrm{TS}$} & \multicolumn{2}{|c|}{ CS } & \multicolumn{2}{|c|}{ S } & \multicolumn{2}{|c|}{ SS } & \multicolumn{2}{|c|}{ Amount } & \multirow[b]{2}{*}{ Mean } \\
\hline & $\mathrm{F}$ & $\%$ & $\mathrm{~F}$ & $\%$ & $\mathrm{~F}$ & $\%$ & $\mathrm{~F}$ & $\%$ & $\mathrm{~F}$ & $\%$ & $\begin{array}{c}\text { Amoun } \\
\mathrm{t}\end{array}$ & $\%$ & \\
\hline $\mathrm{L}_{1}$ & 0 & 0 & 2 & 6.7 & 1 & 3.3 & 27 & 90.0 & 0 & 0 & 30 & 100 & 3.8 \\
\hline $\mathrm{L}_{2}$ & 1 & 3.3 & 2 & 6.7 & 8 & 26.7 & 19 & 63.3 & 0 & 0 & 30 & 100 & 3.5 \\
\hline $\mathrm{L}_{3}$ & 0 & 0 & 2 & 6.7 & 9 & 30 & 19 & 63.3 & 0 & 0 & 30 & 100 & 3.6 \\
\hline $\mathrm{L}_{4}$ & 1 & 3.3 & 2 & 6.7 & 4 & 13.3 & 23 & 76.7 & 0 & 0 & 30 & 100 & 3.6 \\
\hline $\mathrm{L}_{5}$ & 3 & 10 & 2 & 6.7 & 10 & 33.3 & 15 & 50 & 0 & 0 & 30 & 100 & 3.2 \\
\hline $\mathrm{L}_{6}$ & 0 & 0 & 5 & 16.7 & 10 & 33.3 & 15 & 50 & 0 & 0 & 30 & 100 & 3.3 \\
\hline $\mathrm{L}_{7}$ & 0 & 0 & 6 & 20 & 8 & 26.7 & 16 & 53,3 & 0 & 0 & 30 & 100 & 3.3 \\
\hline $\mathrm{L}_{8}$ & 0 & 0 & 3 & 10 & 8 & 26.7 & 19 & 63.3 & 0 & 0 & 30 & 100 & 3.5 \\
\hline $\mathrm{L}_{9}$ & 0 & 0 & 3 & 10 & 9 & 30 & 18 & 60 & 0 & 0 & 30 & 100 & 3.5 \\
\hline $\mathrm{L}_{10}$ & 0 & 0 & 3 & 10 & 7 & 23.3 & 20 & 66.7 & 0 & 0 & 30 & 100 & 3.5 \\
\hline $\mathrm{L}_{11}$ & 0 & 0 & 3 & 10 & 6 & 20 & 21 & 70 & 0 & 0 & 30 & 100 & 3.6 \\
\hline $\mathrm{L}_{12}$ & 0 & 0 & 0 & 0 & 7 & 23.3 & 23 & 76.7 & 0 & 0 & 30 & 100 & 3.8 \\
\hline $\mathrm{L}_{13}$ & 1 & 3.3 & 5 & 16.7 & 6 & 20 & 18 & 60 & 0 & 0 & 30 & 100 & 3.3 \\
\hline $\mathrm{L}_{14}$ & 0 & 0 & 1 & 3.3 & 4 & 13.3 & 25 & 83.4 & 0 & 0 & 30 & 100 & 3.8 \\
\hline $\mathrm{L}_{15}$ & 1 & 3.3 & 0 & 0 & 6 & 20 & 23 & 76.7 & 0 & 0 & 30 & 100 & 3.7 \\
\hline \multicolumn{13}{|c|}{ Average } & 3.5 \\
\hline
\end{tabular}

Source : Primary Data Processed (2021)

Based on the data of respondents' responses in table 9 it can be seen that the average respondent's answers to all statements are at intervals of $3.50<\mathrm{a} \leq 4.20$. This shows that the respondent agreed with the statement submitted regarding the work environment variable $\left(\mathrm{X}_{1}\right)$.

Description of Perceived Organizational Support Variables $\left(\mathrm{X}_{2}\right)$

Table 10. Respondents Response Regarding Perceived Organizational Support $\left(\mathrm{X}_{2}\right)$

\begin{tabular}{|c|c|c|c|c|c|c|c|c|c|c|c|c|c|}
\hline \multirow{2}{*}{ Item } & \multicolumn{2}{|c|}{ STS } & \multicolumn{2}{|c|}{$\mathrm{TS}$} & \multicolumn{2}{|c|}{$\mathrm{CS}$} & \multicolumn{2}{|c|}{$S$} & \multicolumn{2}{|c|}{ SS } & \multicolumn{2}{|c|}{ Amount } & \multirow{2}{*}{ Mean } \\
\hline & $\mathrm{F}$ & $\%$ & $\mathrm{~F}$ & $\%$ & $\mathrm{~F}$ & $\%$ & $\mathrm{~F}$ & $\%$ & $\mathrm{~F}$ & $\%$ & Amount & $\%$ & \\
\hline$P_{1}$ & 0 & 0 & 12 & 40 & 12 & 40 & 6 & 20 & 0 & 0 & 30 & 100 & 2.8 \\
\hline $\mathrm{P}_{2}$ & 0 & 0 & 13 & 43.4 & 8 & 26.6 & 9 & 30 & 0 & 0 & 30 & 100 & 2.9 \\
\hline $\mathrm{P}_{3}$ & 0 & 0 & 5 & 16.7 & 15 & 50 & 10 & 33.3 & 0 & 0 & 30 & 100 & 3.1 \\
\hline $\mathrm{P}_{4}$ & 0 & 0 & 2 & 6.6 & 14 & 46.7 & 14 & 46.7 & 0 & 0 & 30 & 100 & 3.4 \\
\hline $\mathrm{P}_{5}$ & 0 & 0 & 8 & 26.6 & 11 & 36.7 & 11 & 36.7 & 0 & 0 & 30 & 100 & 3.1 \\
\hline $\mathrm{P}_{6}$ & 0 & 0 & 11 & 36.7 & 11 & 36.7 & 8 & 26.6 & 0 & 0 & 30 & 100 & 2.9 \\
\hline $\mathrm{P}_{7}$ & 0 & 0 & 10 & 33.3 & 12 & 40 & 8 & 26.7 & 0 & 0 & 30 & 100 & 2.9 \\
\hline $\mathrm{P}_{8}$ & 0 & 0 & 7 & 23.3 & 14 & 46.7 & 9 & 30 & 0 & 0 & 30 & 100 & 3.0 \\
\hline & & & & & & Aver & & & & & & & 3.0 \\
\hline
\end{tabular}

Source : Primary Data Processed (2021)

Based on the data of respondents' responses in table 10. it can be seen that the average respondent's answers to all statements are at intervals of $3.00<\mathrm{a} \leq 4.20$. This shows that the respondents ordinary with the statements submitted regarding the perceived organizational support variable $\left(\mathrm{X}_{2}\right)$. 


\section{JURNAL EKONOMI}

Description of Employee Engagement Variables $\left(\mathrm{Y}_{1}\right)$

Table 11. Respondents Response Regarding Employee Engagement ( $\left.\mathrm{Y}_{1}\right)$

\begin{tabular}{cccccccccccccc}
\hline \multirow{2}{*}{ Item } & \multicolumn{2}{c}{ STS } & \multicolumn{2}{c}{ TS } & \multicolumn{2}{c}{ CS } & \multicolumn{3}{c}{ S } & \multicolumn{3}{c}{ SS } & \multicolumn{2}{c}{ Amount } & \multirow{2}{*}{ Mean } \\
& $\mathrm{F}$ & $\%$ & $\mathrm{~F}$ & $\%$ & $\mathrm{~F}$ & $\%$ & $\mathrm{~F}$ & $\%$ & $\mathrm{~F}$ & $\%$ & Amount & $\%$ & \\
\hline E1 & 0 & 0 & 0 & 0 & 11 & 37 & 19 & 63 & 0 & 0 & 30 & 100 & 3.6 \\
E2 & 0 & 0 & 0 & 0 & 12 & 40 & 18 & 60 & 0 & 0 & 30 & 100 & 3.6 \\
E3 & 0 & 0 & 0 & 0 & 16 & 53 & 14 & 47 & 0 & 0 & 30 & 100 & 3.4 \\
E4 & 0 & 0 & 0 & 0 & 11 & 37 & 19 & 63 & 0 & 0 & 30 & 100 & 3.6 \\
E5 & 0 & 0 & 0 & 0 & 12 & 40 & 18 & 60 & 0 & 0 & 30 & 100 & 3.6 \\
E6 & 0 & 0 & 0 & 0 & 15 & 50 & 15 & 50 & 0 & 0 & 30 & 100 & 3.5 \\
E7 & 1 & 3.4 & 0 & 0 & 16 & 53.3 & 13 & 43.3 & 0 & 0 & 30 & 100 & 3.3 \\
E8 & 0 & 0 & 0 & 0 & 13 & 43 & 17 & 57 & 0 & 0 & 30 & 100 & 3.6 \\
E9 & 0 & 0 & 0 & 0 & 22 & 73 & 8 & 27 & 0 & 0 & 30 & 100 & 3.2 \\
E10 & 0 & 0 & 0 & 0 & 12 & 40 & 18 & 60 & 0 & 0 & 30 & 100 & 3.6 \\
& & & & \multicolumn{4}{c}{ Average } & & & & & & 3.5 \\
\hline
\end{tabular}

Source : Primary Data Processed (2021)

Based on the data of respondents' responses in table 11. it can be seen that the average respondent's answers to all statements are at intervals of $3.50<\mathrm{a} \leq 4.20$. This shows that the respondent agreed with the statement submitted regarding the employee engagement variable $\left(\mathrm{Y}_{1}\right)$.

Description of Employee Performance Variables $\left(\mathrm{Y}_{2}\right)$

Table 12. Respondents Response Regarding Employee Performance $\left(\mathrm{Y}_{2}\right)$

\begin{tabular}{|c|c|c|c|c|c|c|c|c|c|c|c|c|c|}
\hline \multirow[b]{2}{*}{$\begin{array}{c}\text { Ite } \\
\mathrm{m}\end{array}$} & \multicolumn{2}{|c|}{ STS } & \multicolumn{2}{|c|}{$\mathrm{TS}$} & \multicolumn{2}{|c|}{$\mathrm{CS}$} & \multicolumn{2}{|c|}{$S$} & \multicolumn{2}{|c|}{ SS } & \multicolumn{2}{|c|}{ Jumlah } & \multirow[b]{2}{*}{$\begin{array}{c}\text { Mea } \\
\mathrm{n}\end{array}$} \\
\hline & F & $\%$ & $\mathrm{~F}$ & $\%$ & $\mathrm{~F}$ & $\%$ & $\mathrm{~F}$ & $\%$ & F & $\%$ & $\begin{array}{c}\text { Jumla } \\
\mathrm{h}\end{array}$ & $\%$ & \\
\hline $\mathrm{K}_{1}$ & 0 & 0 & 0 & 0 & 13 & 43 & 17 & 57 & 0 & 0 & 30 & 100 & 3.6 \\
\hline $\mathrm{K}_{2}$ & 0 & 0 & 0 & 0 & 7 & 23 & 23 & 77 & 0 & 0 & 30 & 100 & 3.8 \\
\hline $\mathrm{K}_{3}$ & 0 & 0 & 0 & 0 & 7 & 23 & 23 & 77 & 0 & 0 & 30 & 100 & 3.8 \\
\hline $\mathrm{K}_{4}$ & 0 & 0 & 0 & 0 & 17 & 57 & 13 & 43 & 0 & 0 & 30 & 100 & 3.4 \\
\hline $\mathrm{K}_{5}$ & 0 & 0 & 0 & 0 & 6 & 20 & 24 & 80 & 0 & 0 & 30 & 100 & 3.8 \\
\hline $\mathrm{K}_{6}$ & 0 & 0 & 9 & 30 & 9 & 30 & 12 & 40 & 0 & 0 & 30 & 100 & 3.1 \\
\hline $\mathrm{K}_{7}$ & 0 & 0 & 10 & 33 & 7 & 23 & 13 & 43 & 0 & 0 & 30 & 100 & 3.1 \\
\hline $\mathrm{K}_{8}$ & 0 & 0 & 0 & 0 & 11 & 37 & 19 & 63 & 0 & 0 & 30 & 100 & 3.6 \\
\hline $\mathrm{K}_{9}$ & 0 & 0 & 0 & 0 & 10 & 33 & 20 & 67 & 0 & 0 & 30 & 100 & 3.6 \\
\hline $\mathrm{K}_{10}$ & 0 & 0 & 2 & 6 & 17 & 57 & 11 & 37 & 0 & 0 & 30 & 100 & 3.3 \\
\hline $\mathrm{K}_{11}$ & 0 & 0 & 3 & 10 & 14 & 47 & 13 & 43 & 0 & 0 & 30 & 100 & 3.3 \\
\hline $\mathrm{K}_{12}$ & 0 & 0 & 3 & 10 & 13 & 43 & 14 & 47 & 0 & 0 & 30 & 100 & 3,3 \\
\hline \multicolumn{13}{|c|}{ Average } & 3.4 \\
\hline
\end{tabular}

Source : Primary Data Processed (2021)

Based on the data of respondents' responses in table 12. it can be seen that the average respondent's answers to all statements are at intervals of $3.40<\mathrm{a} \leq 4.20$. This shows that the respondent agreed with the statement submitted regarding the work environment variable $\left(\mathrm{X}_{1}\right)$.

\subsection{Data Analysis and Hypothesis Testing}

\subsubsection{Outer Model Analysis}

1. Convergent Validity Test

Convergent Validity aims to determine the validity of each relationship between the indicator and its latent construct or variable. The convergent validity of the measurement model with reflexive indicators is assessed based on the correlation between the item score or component score estimated by the SmartPLS program. 


\section{JURNAL EKONOMI}

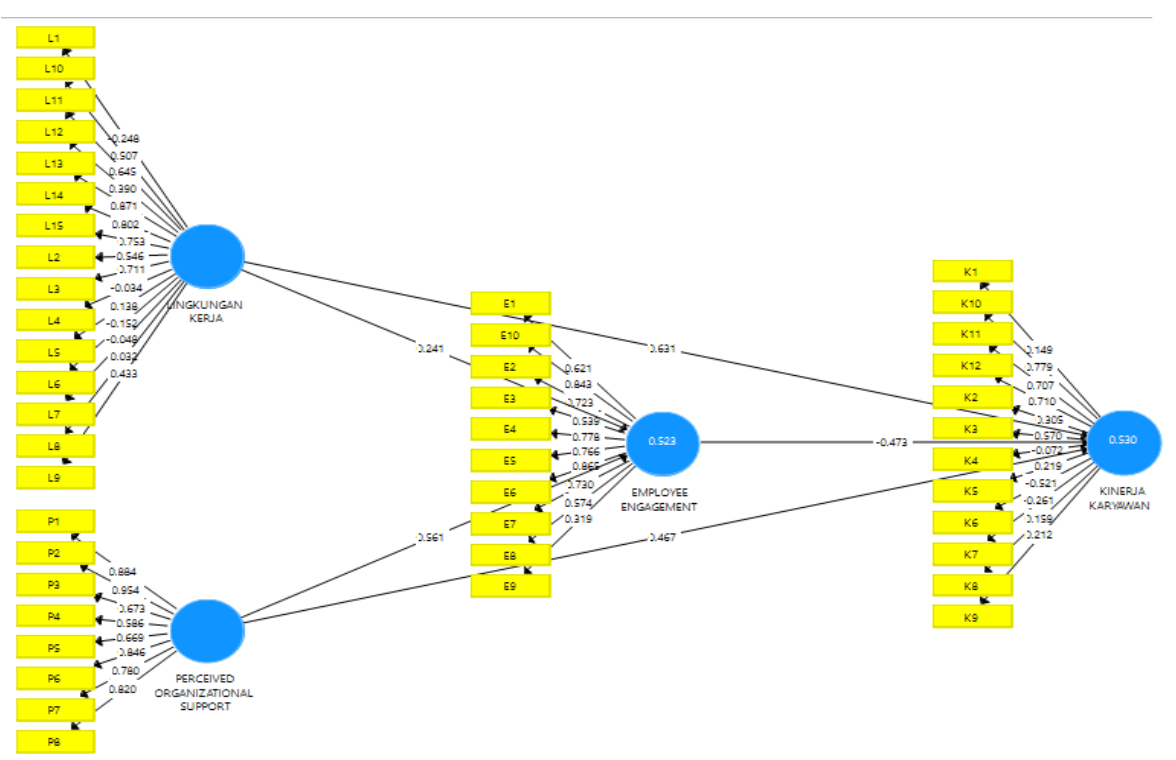

Figure 2. Path Diagram Model 1

Source : Primary Data Processed (2021)

In Figure 2, there is an indicator of a variable that has a loading factor value below 0.7 so that this indicator must be eliminated. For more details, the loading factor value in the image will be explained in detail in table 13 below : 
Table 13. The Value of Loading Factor Path Diagram Model 1

\begin{tabular}{|c|c|c|c|c|}
\hline Item & $\begin{array}{c}\text { Employee } \\
\text { Engagement }\end{array}$ & $\begin{array}{c}\text { Employee } \\
\text { Performance }\end{array}$ & $\begin{array}{c}\text { Work } \\
\text { Environment }\end{array}$ & $\begin{array}{c}\text { Perceived } \\
\text { Oragnizational } \\
\text { Support } \\
\end{array}$ \\
\hline E1 & 0.621 & & & \\
\hline E10 & 0.843 & & & \\
\hline E2 & 0.723 & & & \\
\hline E3 & 0.539 & & & \\
\hline E4 & 0.778 & & & \\
\hline E5 & 0.766 & & & \\
\hline E6 & 0.865 & & & \\
\hline E7 & 0.730 & & & \\
\hline E8 & 0.574 & & & \\
\hline E9 & 0.319 & & & \\
\hline K1 & & 0.149 & & \\
\hline K10 & & 0.779 & & \\
\hline K11 & & 0.707 & & \\
\hline K12 & & 0.710 & & \\
\hline $\mathrm{K} 2$ & & 0.305 & & \\
\hline K3 & & 0.570 & & \\
\hline K4 & & -0.072 & & \\
\hline K5 & & 0.219 & & \\
\hline K6 & & -0.521 & & \\
\hline K7 & & -0.261 & & \\
\hline K8 & & 0.159 & & \\
\hline K9 & & 0.212 & & \\
\hline L1 & & & -0.248 & \\
\hline L10 & & & 0.507 & \\
\hline L11 & & & 0.645 & \\
\hline L12 & & & 0.390 & \\
\hline L13 & & & 0.871 & \\
\hline L14 & & & 0.802 & \\
\hline L15 & & & 0.753 & \\
\hline L2 & & & 0.546 & \\
\hline L3 & & & 0.711 & \\
\hline L4 & & & -0.034 & \\
\hline L5 & & & 0.138 & \\
\hline L6 & & & -0.152 & \\
\hline L7 & & & -0.048 & \\
\hline L8 & & & 0.032 & \\
\hline L9 & & & 0.433 & \\
\hline P1 & & & & 0.884 \\
\hline $\mathrm{P} 2$ & & & & 0.954 \\
\hline P3 & & & & 0.673 \\
\hline $\mathrm{P} 4$ & & & & 0.586 \\
\hline P5 & & & & 0.669 \\
\hline P6 & & & & 0.846 \\
\hline P7 & & & & 0.780 \\
\hline P8 & & & & 0.820 \\
\hline
\end{tabular}

In table 13, 27 Indicators that are colored red must be eliminated, because they have a loading factor value of less than 0.7 . When these 27 indicators are eliminated, a new path diagram model is obtained which results in a new loading factor value. Here is the final path diagram model : 


\section{JURNAL EKONOMI}

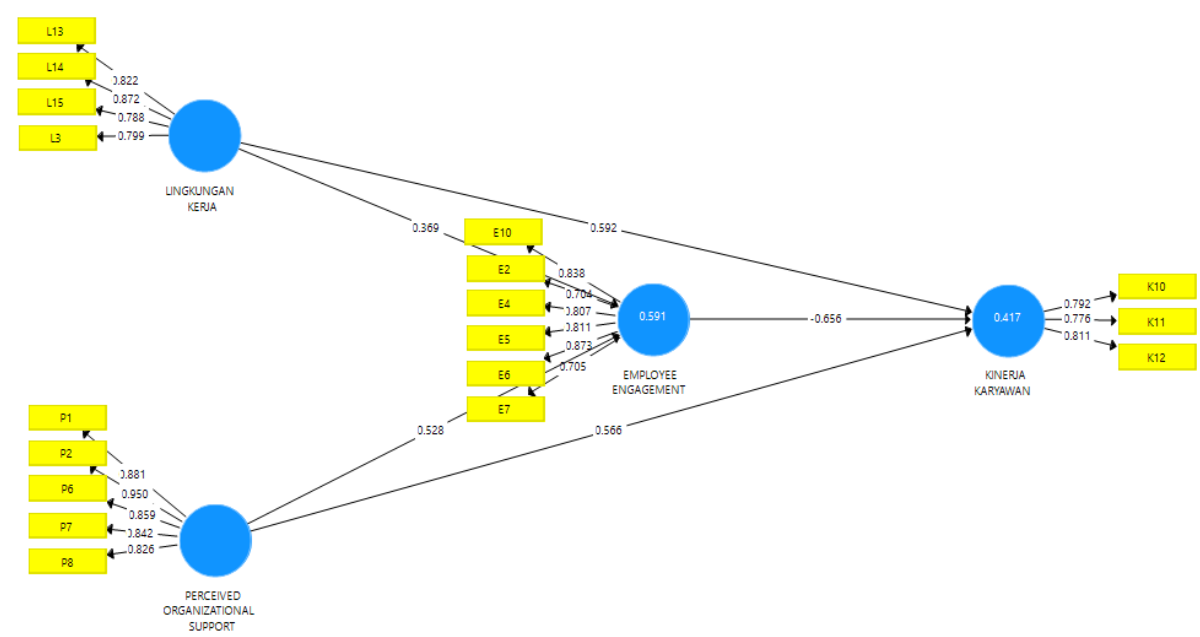

Figure 3. Final Path Diagram Model

Source : Primary Data Processed (2021)

In Figure 3, there is no indicator of the variable that has a loading factor value below 0.7, so this is the final path diagram. For more details, the loading factor value in the final path diagram will be explained in detail in the following table 14 :

Table 14. The Value of Loading Factor Final Path Diagram Model

\begin{tabular}{ccccc}
\hline Item & $\begin{array}{c}\text { Employee } \\
\text { Engagement }\end{array}$ & $\begin{array}{c}\text { Employee } \\
\text { Performance }\end{array}$ & $\begin{array}{c}\text { Work } \\
\text { Environment }\end{array}$ & $\begin{array}{c}\text { Perceived } \\
\text { Oragnizational } \\
\text { Support }\end{array}$ \\
\hline E10 & 0.838 & & & \\
E2 & 0.704 & & & \\
E4 & 0.807 & & & \\
E5 & 0.811 & & & \\
E6 & 0.873 & & & \\
E7 & 0.705 & & & \\
K10 & & 0.792 & & \\
K11 & & 0.776 & & \\
K12 & & 0.811 & & \\
L13 & & & 0.822 & \\
L14 & & & 0.872 & \\
L15 & & & 0.788 & \\
L3 & & & 0.799 & \\
P1 & & & & 0.881 \\
P2 & & & & 0.859 \\
P6 & & & & \\
P7 & & & & \\
P8 & & & & \\
\hline
\end{tabular}

Source : Primary Data Processed (2021) 


\section{JURNAL EKONOMI}

From the results of data processing with smart PLS 3.0, which can be seen in table 14 above, it showed that all items in each variable in this study have a loading factor value greater than 0.7 . This shows that all items have a high level of validity, so that they pass the requirements of convergent validity.

\section{Average Variance Extracted Test}

To evaluate the discriminant validity, it can be seen by the Average Variance Extracted (AVE) method for each construct or latent variable. The model has better discriminant validity if the square root of AVE for each construct is greater than the correlation between the two constructs in the model. In this study, the AVE values and the square root of AVE for each construct are presented in the following table 15 :

Table 15. Average Variance Extracted (AVE) Value

\begin{tabular}{cc}
\hline & Average Variance Extracted (AVE) \\
\hline Employee Engagement & 0.628 \\
Employee Performance & 0.629 \\
Work Environment & 0.674 \\
Perceived Organizational Support & 0.762 \\
\hline Source : Primary Data Processed (2021)
\end{tabular}

From table 15 it is known that the AVE value of each construct is above 0.5. Therefore there is no convergent validity problem in the model being tested so that the constructs in this research model can be said to have good discriminant validity. This means that all indicators and variables are valid.

\section{Discriminant Validity Test}

The discriminant validity test was conducted to see the correlation between constructs and other constructs. If the square root of average (AVE) value of each construct is greater than the correlation value between the constructs and other constructs in the model, it can be concluded that the construct has a good level of validity.

Table 16. Discriminant Validity Value

\begin{tabular}{ccccc}
\hline & $\begin{array}{c}\text { Employee } \\
\text { Engagement }\end{array}$ & $\begin{array}{c}\text { Employee } \\
\text { Performance }\end{array}$ & $\begin{array}{c}\text { Work } \\
\text { Environment }\end{array}$ & $\begin{array}{c}\text { Perceived } \\
\text { Organizational } \\
\text { Support }\end{array}$ \\
\hline Employee Engagement & 0.792 & & \\
Employee Performance & 0.098 & 0.793 & & \\
Work Environment & 0.609 & 0.450 & 0.821 & 0.873 \\
Perceived Organizational Support & 0.695 & 0.379 & 0.455 & \\
\hline \multicolumn{2}{c}{ Source : Primary Data Processed (2021) }
\end{tabular}

Source : Primary Data Processed (2021)

In table 16, the comparison of the values of the AVE root value shows that each of these values is greater than the correlation between other variables, so it can be concluded that all latent variables in the study have good construct validity and discriminant validity.

\section{Composite Reliability Test}

The outer model is measured not only by assessing convergent validity and discriminant validity but also by looking at the reliability of constructs or latent variables measured by looking at the composite reliability value of the indicator block measuring the construct.

The results of smart PLS 3.0 output for composite reliability and Cronbach alpha values can be seen in the following table: 


\section{JURNAL EKONOMI}

Table 17. Construct Reliability and Validity Value

\begin{tabular}{ccccc}
\hline & $\begin{array}{c}\text { Cronbach's } \\
\text { Alpha }\end{array}$ & Rho_A & $\begin{array}{c}\text { Composite } \\
\text { Reliability }\end{array}$ & $\begin{array}{c}\text { Averagae Variance } \\
\text { Extracted (AVE) }\end{array}$ \\
\hline Employee Engagement & 0.881 & 0.897 & 0.910 & 0.628 \\
Employee Performance & 0.707 & 0.713 & 0.836 & 0.629 \\
Work Environment & 0.839 & 0.850 & 0.892 & 0.674 \\
Perceived Organizational Support & 0.921 & 0.936 & 0.941 & 0.762 \\
\hline
\end{tabular}

Source : Primary Data Processed (2021)

Table 17. shows the value of composite reliability for all constructs above 0.70 . Thus it can be concluded that all constructs have good reliability in accordance with the required minimum value limit.

\section{Cronbach Alpha Test}

The outer model is not only measured by assessing the convergent validity and discriminant validity, it can also be done by looking at the construct reliability or latent variables measured by looking at the cronbach alpha value of the indicator block measuring the construct. The construct is declared reliable if the cronbach alpha value is greater than 0,60 . Table 4.14 shows that the cronbach alpha value for all constructs is above 0.60 . Thus it can be concluded that all constructs have good reliability in accordance with the required minimum value limits.

\subsubsection{Inner Model Analysis}

1. $\mathrm{R}^{2}$ Analysis

Table 18. R Square Value

\begin{tabular}{ccc}
\hline & R. Square & R. Square Adjusted \\
\hline Employee Engagement & 0.591 & 0.561 \\
Employee Performance & 0.417 & 0.349 \\
\hline Source : Primary Data Processed (2021)
\end{tabular}

Based on table 18 it is known that the R-Square value for the employee engagement variable is 0.59 which can be interpreted that the magnitude of the influence of work environment variables and perceived organizational support on employee engagement is $59 \%$ while the remaining $41 \%$ is explained by other variables outside of this study. The R-Square value for employee performance variables is 0.41 which means that $41 \%$ of employee performance variables are influenced by work environment variables and perceived organizational support, while the remaining $59 \%$ is influenced by other variables outside of this study.

2. $\mathrm{Q}^{2}$ Analysis

The $\mathrm{Q}^{2}$ value of structural model testing is carried out by looking at the $\mathrm{Q}^{2}$ (predictive relevance) value. To calculate $\mathrm{Q}^{2}$ the formula can be used :

$$
\begin{aligned}
& \mathrm{Q}^{2}=1-\left(1-\mathrm{R} 1^{2}\right)\left(1-\mathrm{R} 2^{2}\right) \\
& \mathrm{Q}^{2}=1-(1-0,591)(1-0,417) \\
& \mathrm{Q}^{2}=1-(0,409 \times 0,583) \\
& \mathrm{Q}^{2}=1-0,238447 \\
& \mathrm{Q}^{2}=0,761553
\end{aligned}
$$

The results of the calculation of $\mathrm{Q}^{2}$ show that the value of $\mathrm{Q}^{2}$ is 0.761553 . According to Ghozali, (2014) the value of $\mathrm{Q}^{2}$ can be used to measure how well the observed value is generated by the model and also its parameter estimates. $\mathrm{A} \mathrm{Q}^{2}$ value greater than 0 (zero) indicates that the model is good enough, while a $\mathrm{Q}^{2}$ value less than 0 (zero) indicates that the model has less predictive relevance. In this research model, the construct or endogenous latent variable has a $\mathrm{Q}^{2}$ value greater than 0 (zero) so that the predictions made by the model are considered relevant. 
3. $\mathrm{F}^{2}$ Analysis

Table 19. $\mathrm{F}^{2}$ Value

\begin{tabular}{ccccc}
\hline & $\begin{array}{c}\text { Employee } \\
\text { Engagement }\end{array}$ & $\begin{array}{c}\text { Employee } \\
\text { Performance }\end{array}$ & $\begin{array}{c}\text { Work } \\
\text { Environment }\end{array}$ & $\begin{array}{c}\text { Perceived } \\
\text { Organizational } \\
\text { Support }\end{array}$ \\
\hline Employee Engagaement & & 0.301 & & \\
Employee Performance & & & & \\
Work Environment & 0.264 & 0.377 & & \\
Perceived Organizational Support & 0.540 & 0.283 & \\
\hline
\end{tabular}

Source : Primary Data Processed (2021)

Based on these criteria, it can be stated as follows:

a. The influence of work environment on employee engagement has medium $\mathrm{F}^{2}(0.264)$

b. The effect of perceived organizational support on employee engagement has a strong $F^{2}(0.540)$

c. The effect of employee engagement on employee performance has a medium $\mathrm{F}^{2}(0.301)$

d. The influence of the work environment on employee performance has a strong $\mathrm{F}^{2}(0.377)$

e. The effect of perceived organizational support on employee performance has a medium $\mathrm{F}^{2}(0.283)$.

\subsubsection{Bootstrapping Result}

In PLS, testing of each relationship is carried out using a simulation with the bootstrapping method of the sample. This test aims to minimize the problem of research data abnormalities. The test results with the bootstrapping method from the SEM PLS analysis are as follows :

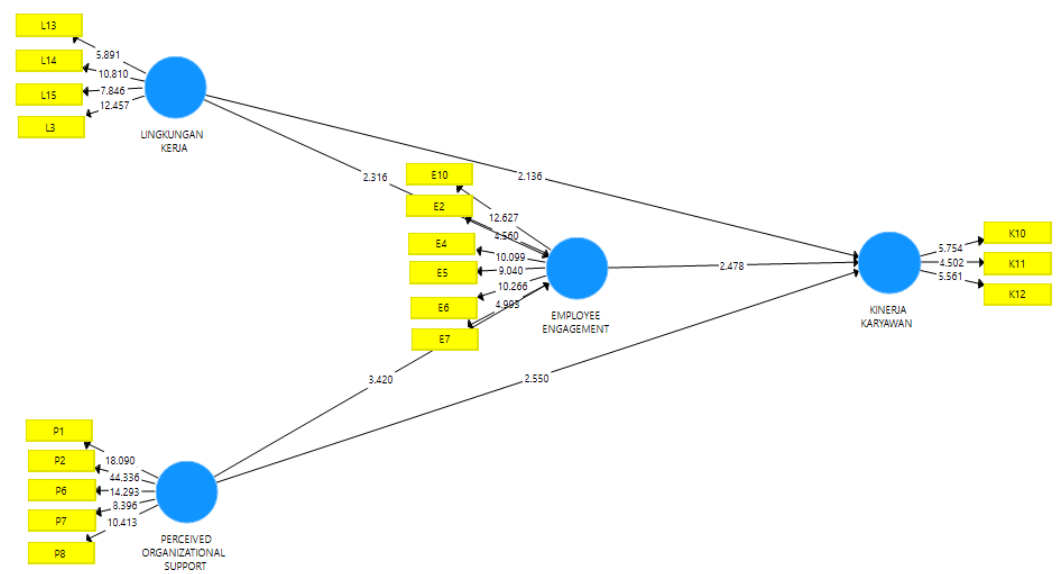

Figure 4. Bootstrapping Output

Source : Primary Data Processed (2021)

4. Direct Effect Analysis

Whether a proposed hypothesis is accepted or not, it is necessary to test the hypothesis using the bootstrapping function on Smart PLS 3.0. The hypothesis is accepted when the significance level is less than 0.05 or the $t$-value exceeds the critical value. The t-statistics value for the $5 \%$ significance level is 1.96 . 
Table 20. Path Coefficient Result

\begin{tabular}{|c|c|c|c|c|c|c|c|}
\hline & Variabel & $\begin{array}{c}\text { Original } \\
\text { Sample } \\
(\mathrm{O})\end{array}$ & $\begin{array}{l}\text { Sample } \\
\text { Mean } \\
(\mathrm{M})\end{array}$ & $\begin{array}{c}\text { Standard } \\
\text { Deviation } \\
\text { (STDEV) }\end{array}$ & $\begin{array}{c}\mathrm{T} \\
\text { Statistics }\end{array}$ & $\begin{array}{c}\mathrm{P} \\
\text { Values }\end{array}$ & Result \\
\hline H1 & $\begin{array}{c}\text { Work environment }>\text { Employee } \\
\text { engagement }\end{array}$ & 0.369 & 0.407 & 0.159 & 2.316 & 0.021 & Accepted \\
\hline $\mathrm{H} 2$ & $\begin{array}{c}\text { Perceived organizational support }> \\
\text { Employee engagement }\end{array}$ & 0.528 & 0.521 & 0.154 & 3.420 & 0.001 & ccepted \\
\hline $\mathrm{H} 3$ & $\begin{array}{c}\text { Work environment }>\text { Employee } \\
\text { performance }\end{array}$ & 0.592 & 0.580 & 0.277 & 2.136 & 0.033 & Accepted \\
\hline $\mathrm{H} 4$ & $\begin{array}{c}\text { Perceived organizational support }> \\
\text { Employee performance }\end{array}$ & 0.566 & 0.562 & 0.222 & 2.550 & 0.011 & Accepted \\
\hline H5 & $\begin{array}{c}\text { Employee engagement }>\text { Employee } \\
\text { performance }\end{array}$ & 0.656 & 0.668 & 0.265 & 2.478 & 0.014 & Accepted \\
\hline
\end{tabular}

Source: The Results of The Study Were Processed with Smart PLS 3.0 (2021)

5. Indirect Effect Analysis

To see whether employee engagement mediates between the work environment and perceived organizational support on employee performance, it can be analyzed through the following table 21:

Table 21. Path Coefficient Result

\begin{tabular}{|c|c|c|c|c|c|c|c|}
\hline & Variabel & $\begin{array}{l}\text { Original } \\
\text { Sample } \\
(\mathrm{O})\end{array}$ & $\begin{array}{l}\text { Sample } \\
\text { Mean } \\
\text { (M) }\end{array}$ & $\begin{array}{l}\text { Standard } \\
\text { Deviation } \\
\text { (STDEV) }\end{array}$ & $\underset{\text { Statistics }}{\mathrm{T}}$ & $\begin{array}{c}\mathrm{P} \\
\text { Values }\end{array}$ & Hasil \\
\hline H6 & $\begin{array}{c}\text { Work environment }>\text { Employee } \\
\text { engagement }>\text { Employee performance }\end{array}$ & 0.242 & 0.274 & 0.166 & 1.454 & 0.146 & Rejected \\
\hline $\mathrm{H} 7$ & $\begin{array}{c}\text { Perceived organizational support }> \\
\text { Employee engagement }>\text { Employee } \\
\text { performance }\end{array}$ & 0.346 & 0.344 & 0.169 & 2.042 & 0.042 & Accepted \\
\hline
\end{tabular}

\subsection{Discussion}

\subsubsection{Effect of Work Environment on Employee Engagement}

From testing the research results, there is a positive and significant influence between the work environment on employee engagement. This is in accordance with the results of path coefficients with the original sample value of 0.369 which shows a positive number with a t statistics value of $2.316>1.96$ and a $p$ value of $0.021<0.05$, so it can be said that work environment variables have a significant effect on employee engagement variables. These results can be interpreted that the better the work environment, the employee engagement will increase and vice versa. If the work environment is bad, employee engagement will be low.

\subsubsection{Effect of Perceived Organizational Support on Employee Engagement}

From testing the research results, there is a positive and significant influence between perceived organizational support on employee engagement. In accordance with the results of the path coefficients with the original sample value of 0.528 which shows a positive number with a t statistics value of $3.420>1.96$ and a $p$ value of $0.001<0.05$, so it can be said that the variable perceived organizational support has a significant effect on the employee engagement variable. These results can be interpreted that the better the perceived organizational support will increase employee engagement and vice versa. If perceived organizational support is bad, employee engagement will be bad.

\subsubsection{Effect of Work Environment on Employee Performance}

From testing the research results with the partial least square method, there is a positive and significant influence between the work environment on employee performance. In accordance with the results of the path coefficients with the original sample value of 0.592 which shows a positive number with a t statistics value of $2.136>1.96$ and a p value of $0.033<0.05$, so it can be said that work environment variables have a significant effect on employee performance variables. These results can be interpreted that the better the work environment, 
the employee performance will increase and vice versa. If the work environment is bad, the employee's performance will be bad.

\subsubsection{Effect of Perceived Organizational Support on Employee Performance}

From testing the research results using the partial least square method, there is a positive and significant influence between perceived organizational support on employee performance. In accordance with the results of path coefficients with the original sample value of 0.566 which shows a positive number with a $t$ statistics value of $2.550>1.96$ and a p value of $0.011<0.05$, so it can be said that the perceived organizational support variable has a significant effect on employee performance variables. These results can be interpreted that the better the perceived organizational support, the employee performance will increase and vice versa. If perceived organizational support is bad, employee performance will be bad.

\subsubsection{Effect of Employee Engagement on Employee Performance}

From testing the research results with the partial least square method, there is a positive and significant influence between employee engagement on employee performance. In accordance with the results of the path coefficients with the original sample value of 0.656 which shows a positive number with a t statistics value of $2.478>1.96$ and a p value of $0.014<0.05$, so it can be said that the employee engagement variable has a significant effect on employee performance variables. These results can be interpreted that the better employee engagement, the employee performance will increase and vice versa. If employee engagement is low, employee performance will be poor.

\subsubsection{Effect of Work Environment on Employee Performance with Employee Engagement as an Intervening Variable}

From testing the research results using the partial least square method, there is a positive but insignificant influence between the work environment on employee performance and employee engagement as an intervening variable. In accordance with the results of the path coefficients with the original sample value of 0.242 which shows a positive number with a t statistics value of $1.454<1.96$ and a p value of $0.146>0.05$, so it can be said that the employee engagement variable does not interfere with the work environment on employee performance.

\subsubsection{Effect of Perceived Organizational on Employee Performance with Employee Engagement as an Intervening Variable}

From testing the research results with the partial least square method, there is a positive and significant influence between perceived organizational support on employee performance and employee engagement as an intervening variable. In accordance with the results of the path coefficients with the original sample value of 0.346 which shows a positive number with a t statistics value of $2.042>1.96$ and a p value of $0.042<0.05$, so it can be said that the employee engagement variable intervenes in perceived organizational support on employee performance.

\section{Conclusions}

Based on the analysis and discussion of this research, it can be concluded that :

1. PT Y's work environment has a significant effect on employee engagement. This interprets that the work environment is a direct factor affecting the performance of PT Y employees in Surabaya.

2. Perceived organizational support has a significant effect on employee engagement. This explains that the perceived organizational support provided by PT Y in Surabaya can affect the size of employee engagement owned by PT Y employees in Surabaya.

3. The work environment has a significant effect on employee performance. This explains that the conditions of PT Y's work environment in Surabaya directly affect the performance of PT Y's employees in Surabaya.

4. Perceived organizational support has a significant effect on employee performance. This means that good perceived organizational support from PT Y in Surabaya will be able to improve employee performance.

5. Employee engagement has a significant effect on employee performance. This explains that if employees of PT Y have high employee engagement, then employees will work above average and contribute optimally to performance.

6. Employee engagement does not mediate the influence of the work environment on employee performance. This is evidenced by the results of the questionnaire which shows that the employees of PT Y in Surabaya have not felt the working conditions are good enough, so they do not exert their ability to perform optimally. Although, the majority of PT Y's employees in Surabaya have worked for more than 10 years. 
7. Perceived organizational support has a significant effect on employee performance with employee engagement as an intervening variable. With the good perceived organizational support from PT Y, employee engagement will increase. And with this increased sense of attachment, employees will perform their best for the company.

\section{References}

Arnold b bakker, \& michael p leiter. (2010). Work Engagement: A Handbook of Essential Theory and Research. Psychology press.

Baliartati, B. O. (2016). Pengaruh Organizational Support Terhadap Job Satisfaction. Manajemen Dan Pemasaran Jasa, 9(1), 35-52.

Bani, W. R. (2013). Pengaruh Iklim Kerja dan Motivasi Kerja Terhadap Kinerja Pegawai Kantor Camat Koto Tangah Padang (p. 10). Universitas Negeri Padang.

Eisenberger, R., Armeli, S., Rexwinkel, B., Lynch, P. D., \& Rhoades, L. (2001). Komitmen Organisasi. Journal of Applied Psychology, 86(1), 42-51. https://doi.org/10.1037//0021-9010.86.1.42

Eisenberger, R., Stinglhamber, F., Vandenberghe, C., Sucharski, I. L., \& Rhoades, L. (2002). Perceived supervisor support: contributions to perceived organizational support and employee retention. Journal of Applied Psychology, 87(3), 565.

Fauzi, A., \& Nugroho, R. H. (2020). Manajemen Kinerja. Airlangga university press.

Ghozali, I. (2014). Structural Equation Modeling Metode Alternatif dengan Partial Least Squares (PLS). In Badan Penerbit Universitas Diponegoro. Badan Penerbit Universitas Diponegoro.

Harsuko, R. (2011). Boosting Motivation and Performance: HR Empowerment Approach. UB Press: Malang.

Hasibuan, S. P. (2010). Hasibuan. 2010. Organisasi \& Motivasi Dasar Peningkatan Produktivitas.

Nitisemito, A. (2014). Sistem Manajemen Kinerja. Jakarta: Gramedia Pustaka.

Onita Sari Sinaga, \& Abdurrozaq Hasibuan. (2020). Manajemen Kinerja dalam Organisasi (Janner Simarmata (ed.)). Yayasan kita menulis.

Rahman, M. (2017). Ilmu Administrasi (Sabirin (ed.)). CV Sah media.

Sedarmayanti, S., \& Rahadian, N. (2018). Hubungan Budaya Kerja dan Lingkungan Kerja Terhadap Peningkatan Kinerja Pegawai Pada Lembaga Pendidikan Tinggi. Jurnal Ilmu Administrasi: Media Pengembangan Ilmu Dan Praktek Administrasi, 15(1), 151.

Sudaryo, Y., Aribowo, A., \& Sofiati, nunung ayu. (2018). Manajemen Sumber Daya Manusia: Kompensasi Tidak Langsung Dan Lingkungan Kerja Fisik (Theodorus erang (ed.)). ANDI.

Sugiyono, P. D. (2016). metode penelitian kuantitatif, kualitatif,dan R\&D. Alfabeta, Cv.

Sutrisno, S., Fathoni, A., \& Minarsih, M. M. (2016). Pengaruh motivasi dan disiplin kerja terhadap kinerja pegawai di kantor satuan polisi pamong praja kota Semarang. Journal of Management, 2(2).

\section{Biography}

Audina Anggraini is a student in the Faculty of Economics and Business Narotama University Surabaya Indonesia. She is study in management study program with a focus on human resources management.

Dr. Hermien Tridayanti is a Senior Lecturer in the Faculty of Economics and Business Narotama University Surabaya. She got a doctoral from UNTAG Surabaya University, Master of Management from Narotama University Surabaya Indonesia, and Bachelor Degree of Agriculture from UPN Surabaya University. She is now Dean on the Faculty Economy and Business Narotama University Indonesia. Her research interests are in the field of Total Quality Management and Human Resource Management.

Elok Damayanti is a senior lecturer at the Faculty of Economic and Business Narotama University Surabaya. She received a Bachelor of Management degree from STIE Yapan Surabaya University, and a Master of Management from Narotama University. Her research interests are in the field of Marketing and Human Resources Management. 